Published in "Journal of Vertebrate Paleontology 37(2): e1301946, 2017"

which should be cited to refer to this work.

\title{
THE LAST EUROPEAN VARANID: DEMISE AND EXTINCTION OF MONITOR LIZARDS (SQUAMATA, VARANIDAE) FROM EUROPE
}

\author{
GEORGIOS L. GEORGALIS, ${ }^{* 1,2}$ ANDREA VILLA ${ }^{2}$ and MASSIMO DELFINO ${ }^{2,3}$ \\ ${ }^{1}$ Department of Geosciences, University of Fribourg, Chemin du Musée 6, 1700 Fribourg, Switzerland, georgios.georgalis@unifr.ch; \\ ${ }^{2}$ Dipartimento di Scienze della Terra, Università di Torino, Via Valperga Caluso 35, 10125 Torino, Italy, massimo.delfino@unito.it; \\ a.villa@unito.it; \\ ${ }^{3}$ Institut Català de Paleontologia Miquel Crusafont, Universitat Autònoma de Barcelona, Edifici ICTA-ICP, Carrer de les Columnes \\ s/n, Campus de la UAB, 08193 Cerdanyola del Vallès, Barcelona, Spain
}

\begin{abstract}
Remains of a varanid lizard from the middle Pleistocene of the Tourkobounia 5 locality near Athens, Greece are described. The new material comprises cranial elements only (one maxilla, one dentary, and one tooth) and is attributed to Varanus, the genus to which all European Neogene varanid occurrences have been assigned. Previously, the youngest undisputed varanid from Europe had been recovered from upper Pliocene sediments. The new Greek fossils therefore constitute the youngest records of this clade from the continent. Despite being fragmentary, this new material enhances our understanding of the cranial anatomy of the last European monitor lizards and is clearly not referable to the extant Varanus griseus or Varanus niloticus, the only species that could be taken into consideration on a present-day geographic basis. However, these fossils could represent a survivor of the monitor lizards of Asian origin that inhabited Europe during the Neogene.
\end{abstract}

Citation for this article: Georgalis, G. L., A. Villa, and M. Delfino. 2017. The last European varanid: demise and extinction of monitor lizards (Squamata, Varanidae) from Europe. Journal of Vertebrate Paleontology. DOI: 10.1080/02724634.2017.1301946.

\section{INTRODUCTION}

Monitor lizards (Varanidae) constitute a diverse clade of squamates that inhabit Africa, southern continental Asia, the Philippines, Indonesia and adjacent islands, and Australia (Pianka et al., 2004). This clade contains more than 70 extant species, with new ones being frequently described (Doughty et al., 2014; Maryan et al., 2014; Weijola et al., 2016). Varanids range greatly in size and include the largest known terrestrial lizards ( = nonsnake squamates), both extinct and extant (Pianka et al., 2004). Despite their wide extant distribution, their fossil record is sparse. The first varanids are identified with certainty in the early Eocene of western Europe. The clade is present there in the Paleogene and throughout the Neogene, whereas it has few, sporadic occurrences in the Paleogene of North America, the Paleogene, Neogene, and Quaternary of Africa and Asia, and the Neogene and Quaternary of Australia (Estes, 1983; Delfino et al., 2004; Pianka et al., 2004; Smith et al., 2008; Holmes et al., 2010). Although scarce, fossil varanids have been known since the middle of the 19th century (Gaudry, 1862). Their European pre-Pleistocene record is by far the most abundant, with specimens having been recovered from several localities across the continent (Fejérváry, 1918, 1935; Pianka et al., 2004; Delfino et al., 2013).

In this paper, we describe new varanid cranial material from the middle Pleistocene of Tourkobounia 5, near Athens, Greece, that represents the youngest record of Varanidae from Europe and confirms a longer survivorship and later extinction of monitor lizards on this continent.

*Corresponding author.
Institutional Abbreviations-MDHC, Department of Earth Sciences, University of Turin, Turin, Italy; MNCN, Museo Nacional de Ciencias Naturales-CSIC, Madrid, Spain; MNHN, Muséum national d'Histoire naturelle, Paris, France; SMF, Senckenberg Museum, Frankfurt, Germany; TMP, Royal Tyrrell Museum, Drumheller, Alberta, Canada; UU, collection of the University of Utrecht; ZFMK, Zoologisches Forschungsmuseum Koenig, Bonn, Germany.

\section{MATERIALS AND METHODS}

All varanid specimens described in this paper were found at the earliest middle Pleistocene locality of Tourkobounia 5, near Athens, Greece. They are part of the collection of the University of Utrecht. Comparative material of extant varanids was studied at MDHC, MNCN, MNHN, SMF, TMP, and ZFMK.

The following specimens of extant species of Varanus were studied: Varanus acanthurus (SMF 11639, SMF 11642, ZFMK 5225, ZFMK 54252), Varanus albigularis (SMF 11543, SMF 21573, SMF 26580, SMF 34049, SMF 40162, SMF 54758, ZFMK 5138, ZFMK 83428), Varanus beccarii (SMF 11637), Varanus bengalensis (MNHN 1883-1828, MNHN 1886-634, MNHN 1886649, SMF 11550, SMF 11554, SMF 32956, SMF 40160, SMF 40179, SMF 60428, SMF 63456, SMF 71569, SMF 71570, TMP 85.16.5, TMP 90.7.360, ZFMK 14872, ZFMK14873, ZFMK 59018, ZFMK 70425), Varanus caudolineatus (SMF 40086), Varanus cumingi (SMF 11577, SMF 76293), Varanus doreanus (SMF 32290, ZFMK 83429), Varanus dumerilii (SMF 11556, TMP 90.7.271, TMP 90.7.272, TMP 90.7.362, SMF 11557, ZFMK 14876, ZFMK 14877), Varanus eremius (SMF 11648), Varanus exanthematicus (MDHC 335, MNHN 1910-7, MNHM 1952-132, SMF 11544, SMF 11545, SMF 33260, SMF 33261, SMF 40161, ZFMK 14884, ZFMK 17528, ZFMK 21652, ZFMK 38432, ZFMK 63663, ZFMK 63664, ZFMK 76976, ZFMK 76977), Varanus flavescens 
(MNHN 1964-51, SMF 11546, SMF 54157, ZFMK 14878, ZFMK 21653), Varanus giganteus (SMF 53263, ZFMK 14882, ZFMK 84341), Varanus gilleni (SMF 11627), Varanus glebopalma (ZFMK 54847), Varanus gouldi (SMF 11620, SMF 53276, SMF 59018, ZFMK 14885), Varanus grayi (SMF 72156), Varanus griseus (MNHN 1880-4, MNHN 1888-196, MNHN 1895-366, MNHN 1909-402, MNHN 1973-105, SMF 32911, SMF 33205, SMF 33206, SMF 33254, SMF 33255, SMF 33256, SMF 33257, SMF 33702, SMF 40163, SMF 70678, SMF 74486, SMF 79190 , TMP 90.7.47, ZFMK 7848, ZFMK 14883, ZFMK 21657, ZFMK 53533), Varanus indicus (SMF 32180, TMP 90.7.45, ZFMK 14863, ZFMK 14864, ZFMK 14865, ZFMK 14866, ZFMK 14867, ZFMK 14881), Varanus jobiensis (SMF 75817), Varanus komodoensis (SMF 23189, SMF 37209, SMF 57555, SMF 57556, SMF 68133, ZFMK 64698), Varanus marmoratus (SMF 11571), Varanus mertensi (SMF 53275), Varanus mitchelli (ZFMK 54250), Varanus niloticus (MNCN 40853, MNHN 1887-909, MNHN 1909-20, MNHN 1921-260, MNHN 1921-260 bis, MNHN 1934-339, MNHN 1964-50, MNHN 2005-62, SMF 11615, SMF 11618, SMF 26579, SMF 32250, SMF 32909, SMF 33251, SMF 33252, SMF 33253, SMF 34427, SMF 46912, SMF 47171, SMF 53197, SMF 83055, SMF 83056, TMP 90.7.31, ZFMK 70424, ZFMK 14887, ZFMK 14888, ZFMK 21655, ZFMK 21656, ZFMK 7847), Varanus ornatus (SMF 36173, SMF 54117, ZFMK 14889, ZFMK 87629), Varanus prasinus (SMF 11626, SMF 69454, ZFMK 14868, ZFMK 14869, ZFMK 14870, ZFMK 14871, ZFMK 14874, ZFMK 14875, ZFMK 54845, ZFMK 54846, ZFMK 76978, ZFMK 7929), Varanus rudicollis (MNHN 1973-108, SMF 40207, SMF 59216, SMF 59239, SMF 59242, SMF 67586, TMP 90.7.361, ZFMK 5229, ZFMK 53534, ZFMK 54253), Varanus salvator (MNHN 1886284, MNHN 1888-198, MNHN 1977-04, SMF 11563, SMF 32807, SMF 32908, SMF 33126, SMF 33127, SMF 33128, SMF 33129, SMF 33130, SMF 33131, SMF 33132, SMF 33133, SMF 33134, SMF 35148, SMF 40175, SMF 40176, SMF 40177, SMF 40178, SMF 66647, SMF 69440, SMF 72158, SMF 81057, SMF 86676, SMF 90068, TMP 90.7.221, TMP 90.7.223, TMP 90.7.269, TMP 90.7.273, TMP 90.7.274, ZFMK 14859, ZFMK 14860, ZFMK 14861, ZFMK 21651, ZFMK 70190, ZFMK 70205, ZFMK 70433, ZFMK 91955), Varanus salvadorii (SMF 57878, SMF 58064, SMF 67670, ZFMK 90996, ZFMK 90997), Varanus semirex (ZFMK 54247, ZFMK 54248, ZFMK 54249), Varanus similis (ZFMK 54251, ZFMK 59027), Varanus spenceri (SMF 53277), Varanus storri (ZFMK 14880, ZFMK 54848, ZFMK 54849), Varanus timorensis (TMP 90.7.38, ZFMK 14886, ZFMK 10000), Varanus tristis (SMF 11630), and Varanus varius (TMP 1997.030.0340).

\section{LOCALITY}

Tourkobounia is a fossiliferous fissure fill near Athens, Greece, that consists of five distinct fossiliferous sites, namely, Tourkobounia 1, 2, 3, 4, and 5, spanning from the late Pliocene to the middle Pleistocene. Tourkobounia 1 comprises the oldest fauna, with a late Pliocene age (MN 16), Tourkobounia 2 is earliest early Pleistocene, whereas Tourkobounia 3, 4, and 5 are considered to pertain to the latest early to earliest middle Pleistocene (Symeonidis and de Vos, 1976; Symeonidis and Zapfe, 1976; Reumer and Doukas, 1985). The geological settings of the Tourkobounia locality were described in detail by Sindowski (1951), de Bruijn and van der Meulen (1975), and Symeonidis and de Vos (1976). A diverse micromammal fauna has been described from the middle Pleistocene site of Tourkobounia 5, comprising chiropterans, erinaceomorph and soricomorph eulipotyphlans, rodents, and lagomorphs, but macromammals are restricted to a felid and a cervid (Symeonidis and de Vos, 1976; Reumer and Doukas, 1985).

Among reptiles from Tourkobounia 5, only a few snakes have been briefly described to date. These include an indeterminate scolecophidian, the natricine Natrix sp., and the colubrines
Elaphe quatuorlineata and Zamenis longissimus (Szyndlar, 1991a, 1991b). The herpetofauna from this fossil locality will be described elsewhere.

\section{SYSTEMATIC PALEONTOLOGY}

\author{
REPTILIA Laurenti, 1768 \\ SQUAMATA Oppel, 1811 \\ VARANIDAE Gray, 1827 (sensu Estes et al., 1988) \\ VARANUS Merrem, 1820 \\ VARANUS sp.
}

(Figs. 1, 2)

Material-UU TB5 1001, one right maxilla (Fig. 1); UU TB5 1002, one partial right dentary (Fig. 2A, B); UU TB5 1003, one isolated tooth (Fig. 2C, D).

\section{ANATOMICAL DESCRIPTION}

Right Maxilla-The maxilla (UU TB5 1001) is fragmentary, lacking the anterior region (probably the region corresponding to the first three tooth positions) and the posterior tip (Fig. 1). The preserved part is moderately robust and $17 \mathrm{~mm}$ long. The facial process is not fully preserved, but its anterior, ascending edge develops a medial lamina that shows a distinct ventromedial fold. On the dorsal surface of this fold, there is a wide and slightly anteroposteriorly elongated vomeronasal foramen. The foramen is flanked laterally by a ridge-like structure (a lappet), which marks the dorsal edge of the medial lamina. Because it is broken, the degree of development of this lappet cannot be determined. Because of its presence, however, the vomeronasal foramen opens at the base of the medial side of the anterior premaxillary process. A very low ridge is also visible on the dorsal surface of the lateral margin of the same process. The palatal shelf is broken, but a large superior dental foramen is visible by the posterior end of the fragment. The contact between the ventromedial fold and the palatal shelf forms a large, posteriorly open cavity. Five complete tooth positions are preserved (a sixth position may have been present posteriorly). Two of them house well-preserved teeth. The most posterior position is occupied by the base of a third tooth. The most anterior, incomplete position bears a small basal portion of another tooth. The teeth are subpleurodont, elongated, conical, and pointed. Their tips are slightly posteromedially recurved and slightly labiolingually compressed, and their bases are slightly swollen lingually. Unserrated carinae are present on their anterior and posterior margins. Striations indicating infolding of dentine are present on the bases both lingually and labially. A spongy tissue connects the teeth to the alveolar portion of the maxilla. The longest tooth is roughly $4 \mathrm{~mm}$ in length. The lateral surface of the maxilla is smooth, with a row of six anteroposteriorly aligned ventrolateral foramina near the alveolar margin. Most foramina are small, but the posterior-most one is much larger than the others. Near the anterior end of the maxilla, a rather large foramen opens posterolaterally above the line of ventrolateral foramina.

Right Dentary - The fragmentary dentary (UU TB5 1002), lacking the anterior portion and the posterior processes (Fig. 2A, $\mathrm{B}$ ), is $15.7 \mathrm{~mm}$ long. The Meckelian fossa is wide and entirely open medially. The subdental ridge is broken, and it is not possible to determine to what extent it originally covered the fossa. Four complete tooth positions and a partial anterior fifth are preserved. The bases of two teeth are preserved. They are connected to the bone by a spongy tissue and show striae on both the lingual and the labial surfaces. The posterior opening of the alveolar canal is located by the last tooth position, and the intramandibular septum continues posteriorly as a ridge fused to the wall of the Meckelian fossa. Although it is partially broken, the superior posterior process appears to bend distinctly dorsally. 
European fossil record, lanthanotids are totally absent, whereas helodermatids and necrosaurids are confined strictly to the Paleogene (Rage, 2013). Within varanids, European fossils have only been attributed to the genera Saniwa and Varanus. The differentiation between the two is mostly based on stratigraphic rationale and osteological features of bones other than maxillae or dentaries, but a longer posterior process of the maxilla is generally present in Saniwa (Estes, 1983). In any case, members of Saniwa are completely absent from Europe after the Eocene (Augé, 2005), and Varanus is the only valid varanoid genus that has been reported from European Neogene localities to date (Delfino et al., 2013). Varanus is also the sole recognized genus of Quaternary and extant varanids (Pianka et al., 2004). Furthermore, the morphology of the Tourkobounia 5 specimens is consistent with attribution to Varanus, so the material can be confidently referred to this genus.

The morphology of the maxilla is different from that of the two extant species that could have potentially extended their range to Greece in the Middle Pleistocene: Varanus niloticus (Linnaeus, 1766) and Varanus griseus (Daudin, 1803). The former is characterized, along with all the other African taxa (Varanus ornatus Gray, 1845, Varanus exanthematicus Bosc, 1792, and Varanus albigularis Daudin, 1802), by posterior globular teeth in adult individuals (D'Amore, 2015), whereas V. griseus, among others, is characterized by the absence of the medial lamina that is clearly developed in UU TB5 1001 on the sloping anterior edge of the facial process. The presence of this lamina in UU TB5 1001 is congruent with that of the extinct Varanus marathonensis Weithofer, 1888, from the late Miocene of Pikermi (also near Athens), as well as that of several extant Asian taxa, but the preservational status and the poor knowledge of the osteology of extant species precludes any specific identification.

\section{DISCUSSION AND CONCLUSIONS}

Varanids first appear in the European fossil record during the Eocene. They are totally absent from the Oligocene faunas of the continent and seem to appear again after the early Miocene (Rage, 2013). It remains plausible that these former European Paleogene varanids were victims of the 'Grande Coupure,' going extinct at the end of the Eocene and that the Miocene forms are the product of a younger wave of dispersal (Augé, 1993; Rage, 2013). On the basis of the available data, however, this cannot be demonstrated with certainty. In any case, all Neogene European varanids appear to be members of Varanus, and they seem to have dispersed into Europe around the early Miocene (Delfino et al., 2013; Cerňanský et al., 2015). In fact, the earliest evidence of the genus on the European continent is recorded in the early Miocene of Spain (Delfino et al., 2013). Whether these early Miocene immigrants originated directly from Africa (Holmes et al., 2010) or have Asian affinities (Conrad et al., 2012; Vidal et al., 2012; Rage, 2013) cannot be demonstrated with certainty. The occurrence of Varanus-like forms in the late Eocene and early Oligocene of Egypt (Smith et al., 2008; Holmes et al., 2010) favors an African origin, but the Asian record is too poor to offer any insights. The fact that the maxilla from Tourkobounia 5 does not show any relationship with extant African taxa $(V$. albigularis, $V$. exanthematicus, $V$. griseus, $V$. niloticus, $V$. ornatus) suggests Asian affinities, as already reported for the extinct Varanus amnhophilis Conrad et al., 2012, from the late Miocene of Samos (Conrad et al., 2012).

Whatever their exact origin may have been, Varanus spp. rapidly achieved a wide distribution throughout Europe during the Miocene. Fossils attributed to this genus have been described from localities in several countries, including Austria, Germany, Greece, Hungary, Italy, Moldova, Portugal, Romania, Spain, and Ukraine (Weithofer, 1888; Roger, 1898, 1900; Fejérváry, 1918, 1935; Hoffstetter, 1969; Antunes and Rage, 1974; Antunes and Mein, 1981; Lungu et al., 1983; Zerova and Chkhikvadze, 1986; Delfino, 2002; Hír and Venczel, 2005; Rage and Bailon, 2005; Venczel, 2005, 2006; Conrad et al., 2012; Delfino et al., 2013; Böhme and Vasilyan, 2014; Colombero et al., 2014; Venczel and Hír, 2015). During the Pliocene, there is an apparent contraction in their distribution, because described specimens are known only from Hungary (Bolkay, 1913; Fejérváry, 1918), France (Bailon, 1991; Bailon and Blain, 2007), and Spain (Sanz, 1977; Bailon, 1992). Reports of Pliocene varanids from Moldova and Ukraine (Zerova and Chkhikvadze, 1986) lack descriptions, figures, and collection numbers and are thus here excluded from consideration. Otherwise, the last reported occurrence of a varanid from the European continent is known from the late Pliocene (MN 16) of Beremend 1, Hungary, part of the type material of Varanus deserticolus (Bolkay, 1913; Rage, 2013). This taxon was established by Bolkay (1913) on the basis of fragments of a dentary and a vertebra. The vertebra, however, was later shown to belong to a large anguid (Fejérváry, 1918; Fejérváry-Lángh, 1923; Estes, 1983), whereas the dentary indeed has varanid affinities and was considered as being similar to Varanus marathonensis from the late Miocene of Pikermi (Fejérváry, 1918; Estes, 1983).

Outside Europe, the last reliable occurrence of a varanid from the northern part of the Mediterranean is known from the late Pliocene of Calta, Turkey (Rage and Sen, 1976). This material has been attributed to the Miocene taxon $V$. marathonensis and pertains to a fairly large animal (about $2.5 \mathrm{~m}$ ) (Rage and Sen, 1976). The available material from Calta consists solely of vertebrae and as such cannot be directly compared with the Tourkobounia 5 varanid. The much smaller size of the Greek specimens may differentiate it from the older Chalta form, but the large foramina present in the former material could suggest a juvenile condition (see below), rendering the basis for such a taxonomic distinction equivocal.

There are two purported occurrences of varanids from the Pleistocene of Europe. The first supposed varanid is from the Late Pleistocene of Arene Candide, Italy (Morelli, 1891). The only known specimen is now considered lost (Delfino, 2002), and its identification as a varanid has been questioned multiple times (Estes, 1983; Holman, 1998; Delfino, 2002). Delfino (2002) noted that this fossil could belong to a large-sized Timon-like lacertid, but owing to some differences between the figured specimen and the standard lacertid lower jaw morphology, he preferred to consider it only as an undetermined lizard. We accept this view herein. The second purported European Pleistocene varanid is from the Middle Pleistocene of the Petralona cave, northern Greece. This specimen was initially mentioned as Varanus aff. marathonis (sic) by Sickenberg (1971), with Kretzoi and Poulianos (1981) referring to this as 'Varanus intermedius Bolkay.' However, this material has never been formally described or figured, and no repository number has been given. Moreover, even the measurements of the supposed two specimens (vertebra: 270 mm; phalanx: $340 \mathrm{~mm}$ ) are apparently erroneous. Even in terms of nomenclature, the Petralona specimen is problematic: Sickenberg (1971) constantly referred to it with an erroneous spelling of V. marathonensis, whereas Kretzoi and Poulianos (1981) apparently referred to what is actually Ophisaurus intermedius Bolkay, 1913, a large anguid, now considered a junior synonym of Pseudopus pannonicus (Fejérváry-Lángh, 1923; Estes, 1983). In any case, after personal investigation from one of us (GLG), we were not able to locate this purported varanid material in the collection where it is supposedly kept (Laboratory of Geology and Paleontology, Aristotle University of Thessaloniki, Greece), and this occurrence is therefore herein considered as anecdotal.

Given that the two previously reported specimens can be disregarded, the Tourkobounia 5 specimens described herein represent the sole substantiated occurrence of varanids from the Pleistocene of Europe, indicating that this clade survived much 
longer in this region than previously thought. The documented restricted distribution of varanids during the European Pliocene clearly reveals that the clade was already in decline, and the absence of younger specimens had been used to infer a possible extinction by the end of that epoch (Bailon and Blain, 2007; Rage, 2013). Judging from their fossil record, it seems that Pliocene varanids were not restricted to the southern margins of Europe but were also present in the central portions of the continent (Hungary). The persistence of varanids in the Pliocene of both south and central Europe is thus consistent with that of other thermophilic taxa that occurred at that time in both regions, such as scolecophidians, erycine booids, and elapids (Rage, 2013). The new Greek Varanus shows that monitor lizards inhabited Europe at least until the middle Pleistocene. It thus seems that Pleistocene European varanids showed a southward contraction of their range, as is the case of other thermophilic taxa, such as agamids, the large anguid Pseudopus, amphisbaenians, scolecophidians, erycines, and 'Oriental vipers' (Szyndlar, 1991a; Delfino, 1997; Delfino et al., 2008; Georgalis et al., 2016). With the available data in hand, it is difficult to conclude with certainty whether climatic change was the only driving force behind the disappearance of varanids from Europe. Additional factors, such as interactions with other taxa (e.g., predation and competition), may have played a role in their final demise. It is worth noting that, although represented by very few remains possibly belonging to a single individual (the size of the maxilla and the dentary is comparable), the monitor lizard from Tourkobounia seems to be significantly smaller than $V$. amnhophilis, which was reported to reach more than $600 \mathrm{~mm}$ in snoutvent length, and $V$. marathonensis, both also known from cranial material (Fejérváry, 1918; Rage and Sen, 1976; Pianka et al., 2004; Conrad et al., 2012). Judging from the presence of a clearly developed medial lamina in the maxilla of the Tourkobounia 5 form, also observed in $V$. marathonensis (Weithofer, 1888), it seems plausible that they both belong to the same lineage. This considerable size reduction between the Miocene and the Pleistocene forms could be tentatively regarded as a survival adaptation of the last European monitor lizards, in an effort to face the lower temperatures of the Pleistocene, in comparison with those of their Neogene predecessors. Such size reduction after extinction events (known as the 'Lilliput effect'; Urbanek, 1993) has been observed in distantly related tetrapod clades (Smith, 1995; Tverdokhlebov et al., 2002). On the other hand, other European reptile clades are known to have reached considerably larger sizes during the Plio-Pleistocene, such as the anguid Pseudopus pannonicus (Klembara, 2012) and giant tortoises (Georgalis and Kear, 2013). Furthermore, the alternative possibility that the specimens described herein belong to a juvenile cannot be excluded. According to Evans (2008), a change in size of the nerve foramina is one of the major ontogenetic changes occurring in the lizard skull, with juveniles having larger foramina that separate into smaller ones during growth. The large foramina on the lateral surfaces of both the maxilla UU TB5 1001 and the dentary UU TB5 1002 could be interpreted as a juvenile condition. Only the discovery of more Pleistocene varanids from Europe will eventually resolve these questions.

\section{ACKNOWLEDGMENTS}

We would like to thank W. Wessels and H. de Bruijn (Utrecht) for the loan of the fossil material and B. Sanchiz (Madrid) for having facilitated its study. We also thank W. Joyce (Fribourg) and D. Kostopoulos, G. Koufos, and E. Tsoukala (Thessaloniki) for valuable comments that enhanced the quality of the manuscript. Comparative material was studied thanks to W. Böhme and D. Rödder (Bonn), J. Gardner (Drumheller), L. Acker and G. Köhler (Frankfurt), M. Domínguez Díaz (Madrid), and S. Bailon (Paris). This work was supported by Fondi di Ateneo
dell'Università di Torino 2015, Generalitat de Catalunya (2014 SGR 416 GRC to M.D.), and Synthesys (FR-TAF-5007 to A.V.; ES-TAF-1975 to M.D.).

\section{LITERATURE CITED}

Antunes, M. T., and P. Mein. 1981. Vertébrés du miocène moyen de Amor (Leiria)-importance stratigraphique. Ciências da Terra 6:169-188.

Antunes, M. T., and J.-C. Rage. 1974. Notes sur la géologie et la paléontologie du Miocène de Lisbonne. XIV: quelques Squamata (Reptilia). Boletim da Sociedade Geológica de Portugal 19:47-60.

Augé, M. 1993. Repartition et dynamisme des faunes de lacertilia et d'amphisbaenia dans l'Eocene Europeen. Palaeovertebrata 22:51-71.

Augé, M., 2005. Evolution des lézards du Paléogène en Europe. Publications Scientifiques du Muséum, Mémoires du Muséum national d'Histoire naturelle, Paris 192:1-369.

Augé, M., and R. Smith. 2009. An assemblage of early Oligocene lizards (Squamata) from the locality of Boutersem (Belgium), with comments on the Eocene-Oligocene transition. Zoological Journal of the Linnean Society 155:148-170.

Bailon, S. 1991. Amphibiens et reptiles du Pliocène et du Quaternaire de France et d'Espagne: mise en place et évolution des faunes. Doctoral dissertation, Université de Paris VII, Paris, France, 499 pp.

Bailon, S. 1992. Escamosos (Reptilia) fósiles del yacimiento de Moreda (Plioceno medio/superior, Granada). Revista Española de Paleontología, Extra 7(Suppl 3):11-15.

Bailon, S., and H.-A. Blain. 2007. Faunes de reptiles et changements climatiques en Europe occidentale autour de la limite PlioPléistocène. Quaternaire 18:55-63.

Böhme, M., and D. Vasilyan. 2014. Ectothermic vertebrates from the late Middle Miocene of Gratkorn (Austria, Styria). Palaeobiodiversity and Palaeoenvironments 94:21-40.

Bolkay, J. 1913. Additions to the fossil herpetology of Hungary from the Pannonian and Praeglacial periode. Mittheilungen aus dem Jahrbuche der königlichen Ungarischen geologischen Reichsanstalt 21:217-230.

Bosc, L. 1792. Lacerta exanthematica. Actes de la Société d'Histoire Naturelle de Paris 1:1-25.

Bruijn, H. de, and A. J. van der Meulen. 1975. The Early Pleistocene rodents from Tourkobounia-1 (Athens, Greece) I and II. Proceedings Koninklijke Nederlandse Akademie van Wetenschappen B 78:314-338.

Čerňanský, A., J.-C. Rage, and J. Klembara. 2015. The Early Miocene squamates of Amöneburg (Germany): the first stages of modern squamates in Europe. Journal of Systematic Palaeontology 13:97128.

Colombero, S., C. Angelone, E. Bonelli, G. Carnevale, O. Cavallo, M. Delfino, P. Giuntelli, P. Mazza, G. Pavia, M. Pavia, and G. Repetto. 2014. The Messinian vertebrate assemblages of Verduno (NW Italy): another brick for a latest Miocene bridge across the Mediterranean. Neues Jahrbuch für Geologie und Paläontologie, Monatschefte 272:287-234.

Conrad, J. L., A. M. Balcarcel, and C. M. Mehling. 2012. Earliest example of a giant monitor lizard (Varanus, Varanidae, Squamata). PLoS ONE 7:e41767.

D'Amore, D. C. 2015. Illustrating ontogenetic change in the dentition of the Nile monitor lizard, Varanus niloticus: a case study in the application of geometric morphometric methods for the quantification of shape-size heterodonty. Journal of Anatomy 226:403-419.

Daudin, F. 1802. Histoire Naturelle, Générale et Particulière des Reptiles; ouvrage faisant suit à l'Histoire naturelle générale et particulière, composée par Leclerc de Buffon; et rédigee par C.S. Sonnini, membre de plusieurs sociétés savantes, vol. 4. F. Dufart, Paris, 397 pp.

Daudin, F. 1803. Histoire Naturelle des Reptiles, vol. 8. F. Dufart, Paris, 439 pp.

Delfino, M. 1997. Blanus from the early Pleistocene of southern Italy: another small tessera from a big mosaic; pp. 89-97 in I. W. Böhme, W. Bischoff, and T. Ziegler (eds.), Herpetologica Bonnensis. SEH, Bonn, Germany.

Delfino, M. 2002. Erpetofaune italiane del Neogene e del Quaternario. Doctoral Thesis, University of Modena and Reggio Emilia, Modena and Reggio Emilia, Italy, $382 \mathrm{pp}$. 
Delfino, M., J.-C. Rage, A. Bolet, and D. M. Alba. 2013. Early Miocene dispersal of the lizard Varanus into Europe: reassessment of vertebral material from Spain. Acta Palaeontologica Polonica 58:731735.

Delfino, M., T. Kotsakis, M. Arca, C. Tuveri, G. Pitruzzella, and L. Rook. 2008. Agamid lizards from the Plio-Pleistocene of Sardinia (Italy) and an overview of the European fossil record of the family. Geodiversitas 30:641-656.

Delfino, M., A. Segid, D. Yosief, J. Shoshani, L. Rook, and Y. Libsekal. 2004. Fossil reptiles from the Pleistocene Homo-bearing locality of Buia (Eritrea, Northern Danakil Depression). Rivista Italiana di Paleontologia e Stratigrafia 110:51-60.

Doughty, P., L. Kealley, A. Fitch, and S. C. Donnellan. 2014. A new diminutive species of Varanus from the Dampier Peninsula, western Kimberley region, Western Australia. Records of the Western Australian Museum 29:128-140.

Estes, R. 1983. Sauria Terrestria, Amphisbaenia. Encyclopedia of Paleoherpetology, Part 10a. Gustav Fisher Verlag, Stuttgart and New York, 249 pp.

Estes, R., K. de Queiroz, and J. Gauthier. 1988. Phylogenetic relationships within Squamata; pp. 99-118 in R. Estes and G. Pregill (eds.), Phylogenetic Relationships of the Lizard Families: Essays Commemorating Charles L Camp. Stanford University Press, Stanford, California.

Evans, S. E. 2008. The skull of lizards and tuatara; pp. 1-347 in C. Gans, A. S. Gaunt, and K. Adler (eds.), Biology of the Reptilia, Volume 20, The Skull of Lepidosauria. Society for the Study of Amphibians and Reptiles, Ithaca, New York.

Fejérváry, G. J. de. 1918. Contributions to a monography on fossil Varanidae and on Megalanidae. Annales Musei Nationales Hungarici, Pars Zoologica 16:341-467.

Fejérváry, G. J. de. 1935. Further contributions to a monograph of the Megalanidae and Fossil Varanidae, with notes on recent varanians. Annales Musei Nationales Hungarici, Pars Zoologica 29:1-130.

Fejérváry-Lángh, A. M. 1923. Beiträge zu einer Monographie der fossilen Ophisaurier. Palaeontologia Hungarica 1:123-220.

Gaudry, A. 1862. Note sur les débris d'oiseaux et de reptiles trouvés à Pikermi, Grèce, suivie de quelques remarques de paléontologie générale. Bulletin de la Société Géologique de France 19:629-640.

Georgalis, G. L., and B. P. Kear. 2013. The fossil turtles of Greece: an overview of taxonomy and distribution. Geobios 46:299-311.

Georgalis, G. L., Z. Szyndlar, B. P. Kear, and M. Delfino. 2016. New material of Laophis crotaloides, an enigmatic giant snake from Greece, with an overview of the largest fossil European vipers. Swiss Journal of Geosciences 109:103-116.

Gray, J. E. 1827. A synopsis of the genera of saurian reptiles, in which some new genera are indicated and others reviewed by actual examination. The Philosophical Magazine, or Annals of Chemistry, Mathematics, Astronomy, Natural History, and General Science 2:54-58.

Hír, J., and M. Venczel. 2005. New middle Miocene vertebrate localities from Subpiatră (Bihor District, Romania). Acta Palaeontologica Romaniae 5:211-221.

Hoffstetter, R. 1969. Présence de Varanidae (Reptilia, Sauria) dans le Miocène de Catalogne. Considérations sur l'histoire de la famille. Bulletin du Muséum National d'Histoire Naturelle 40:1051-1064.

Holman, A. J. 1998. Pleistocene Amphibians and Reptiles in Britain and Europe. Oxford University Press, New York, 254 pp.

Holmes, R. B., A. M. Murray, Y. S. Attia, E. L. Simons, and P. Chatrath. 2010. Oldest known Varanus (Squamata: Varanidae) from the Upper Eocene and Lower Oligocene of Egypt: support for an African origin of the genus. Palaeontology 53:1099-1110.

Kearney, M., and O. Rieppel. 2006. An investigation into the occurrence of plicidentine in the teeth of squamate reptiles. Copeia 2006:337350.

Klembara, J. 2012. A new species of Pseudopus (Squamata, Anguidae) from the early Miocene of Northwest Bohemia (Czech Republic). Journal of Vertebrate Paleontology 32:854-866.

Kretzoi, M., and N. Poulianos. 1981. Remarks on the middle and lower Pleistocene vertebrate fauna in the Petralona Cave. Anthropos (Athens) 8:57-72.

Laurenti, J. N. 1768. Specimen medicum, exhibens synopsin reptilium emendatam cum experimentis circa venena et antidota reptilium austracorum, quod authoritate et consensu. Joan Thomae, Vienna, 217 pp.
Luan, X., C. Walker, S. Dangaria, Y. Ito, R. Druzinsky, K. Jarosius, H. Lesot, and O. Rieppel. 2009. The mosasaur tooth attachment apparatus as paradigm for the evolution of the gnathostome periodontium. Evolution \& Development 11:247-259.

Lungu, A. N., G. A. Zerova, and V. M. Chkhikvadze. 1983. [Primary evidence on the Miocene Varanus of the North Black Sea litoral]. Bulletin of the Academy of Sciences of the Georgian SSR 110:417-420. [Russian, with English summary]

Maryan, B., P. M. Oliver, A. J. Fitch, and M. O'Connell. 2014. Molecular and morphological assessment of Varanus pilbarensis (Squamata: Varanidae), with a description of a new species from the southern Pilbara, Western Australia. Zootaxa 3768:139-158.

McDowell, S. B., and C. M. Bogert. 1954. The systematic position of Lanthanotus and the affinities of anguinomorphan lizards. Bulletin of the American Museum of Natural History 105:1-142.

Merrem, B. 1820. Versuch eines Systems der Amphibien, vol. 8. J. C. Krieger, Marburg, 189 pp.

Morelli, N. 1891. Resti organici rinvenuti nella caverna delle Arene Candide presso Finalmarina. Atti della Società Ligustica di Scienze Naturali e Geografiche 2:171-205.

Oppel, M. 1811. Die Ordnungen, Familien, und Gattungen der Reptilien als Prodrom einer Naturgeschichte derselben. Joseph Lindauer, Munich, $86 \mathrm{pp}$.

Pianka, R. E., D. King, and R. A. King. 2004. Varanoid Lizards of the World. Indiana University Press, Bloomington, Indiana, $587 \mathrm{pp}$.

Rage, J.-C. 2013. Mesozoic and Cenozoic squamates of Europe. Palaeobiodiversity and Palaeoenvironments 93:517-534.

Rage, J.-C., and S. Bailon. 2005. Amphibians and squamate reptiles from the late early Miocene (MN 4) of Béon 1 (Montréal-du-Gers, southwestern France). Geodiversitas 27:413-441.

Rage, J.-C., and S. Sen. 1976. Les amphibiens et les reptiles du Pliocène supérieur de Calta (Turquie). Géologie méditerranéenne 3:127-134.

Reumer, J. W. F., and C. S. Doukas. 1985. Early Pleistocene Insectivora (Mammalia) from Tourkobounia (Athens, Greece). Proceedings Koninklijke Nederlandse Akademie van Wetenschappen B 88:111121.

Roger, O. 1898. Wirbelthierreste aus dem Dinotheriensande, II. Bericht des Naturwissenschaftlichen Vereins für Schwaben und Neuburg (a. V.) in Augsburg 33:385-396.

Roger, O. 1900. Wirbelthierreste aus dem Dinotheriensande, III. Bericht des Naturwissenschaftlichen Vereins für Schwaben und Neuburg (a. V.) in Augsburg 34:53-70.

Sanz, J. 1977. Presencia de Varanus (Sauria, Reptilia) en el Plioceno de Layna (Soria). Trabajos sobre Neogeno-Cuaternario 8:113125 .

Sickenberg, O. 1971. Revision der Wirbeltierfauna der Höhle Petralona. Annales Géologiques des Pays Hélleniques 23:230-264.

Sindowski, K. H. 1951. Zur Geologie des Lykabettos-TurkowuniGebietes bei Athen, mit einem Beitrag über frühdiluviale Wirbeltierfunde aus Spalten. Annales Géologiques des Pays Hélleniques 3:11-21.

Smith, K. T., B.-A. S. Bhullar, and P. A. Holroyd. 2008. Earliest African record of the Varanus stem-clade (Squamata: Varanidae) from the early Oligocene of Egypt. Journal of Vertebrate Paleontology 28:909-913.

Smith, R. M. H. 1995. Changing fluvial environments across the PermianTriassic boundary in the Karoo Basin, South Africa, and possible causes of tetrapod extinctions. Palaeogeography, Palaeoclimatology, Palaeoecology 117:81-104.

Symeonidis, N. K., and J. de Vos. 1976. Großsäugerfunde aus den plistozänen Spaltenfüllungen von Turkovunia in Athen. Annales Géologiques des Pays Hélleniques 28:135-144.

Symeonidis, N., and H. Zapfe. 1976. Primatenzahne (Cercopithecidae) aus einer Pleistozänen Spaltenfullung im Steibruch Tourkobounia, Athen. Annales Géologiques des Pays Hélleniques 28:207-214.

Szyndlar, Z. 1991a. A review of Neogene and Quaternary snakes of Central and Eastern Europe. Part I: Scolecophidia, Boidae, Colubrinae. Estudios Geológicos 47:103-126.

Szyndlar, Z. 1991b. A review of Neogene and Quaternary snakes of Central and Eastern Europe. Part II: Natricinae, Elapidae, Viperidae. Estudios Geológicos 47:237-266.

Tverdokhlebov, V. P., G. I. Tverdokhlebova, M. V. Surkov, and M. J. Benton. 2002. Tetrapod localities from the Triassic of the SE of European Russia. Earth Science Reviews 60:1-66. 
Urbanek, A. 1993. Biotic crises in the history of Upper Silurian graptoloids: a palaeobiological model. Historical Biology 7:29-50.

Venczel, M. 2005. A new Middle Miocene vertebrate fauna from Subpiatrã. Nymphaea, Folia naturae Bihariae 32:23-38.

Venczel, M. 2006. Lizards from the Late Miocene of Polgárdi (W. Hungary). Nymphaea, Folia naturae Bihariae 33:25-38.

Venczel, M., and J. Hír. 2015. Lissamphibians and squamate reptiles from the early middle Miocene of Litke, Northern Hungary. Geobios 48:491-504.

Vidal, N., J. Marin, J. Sassi, F. U. Battistuzzi, S. Donnellan, A. J. Fitch, B. G. Fry, F. J. Vonk, R. C. Rodriguez de la Vega, A. Couloux, and S. B. Hedges. 2012. Molecular evidence for an Asian origin of monitor lizards followed by Tertiary dispersals to Africa and Australasia. Biology Letters 8:853-855.
Weijola, V., S. C. Donnellan, and C. Lindqvist. 2016. A new blue-tailed Monitor lizard (Reptilia, Squamata, Varanus) of the Varanus indicus group from Mussau Island, Papua New Guinea. ZooKeys 568:129-154.

Weithofer, A. 1888. Beiträge zur Kenntniss der Fauna von Pikermi bei Athen. Beiträge zur Paläontologie Österreich-Ungarns 6:225-292.

Zerova, G. A., and V. M. Chkhikvadze. 1986. Neogene varanids of the USSR; pp. 689-694 in Z. Roček (ed.), Studies in Herpetology. Charles University of Prague, Prague, Czech Republic. 